\title{
Blindness and Inwit: James Joyce and the Sirens A Reading of Chapter 11 of Ulysses Arthur Nestrovski
}

“. . . LES PREMIERS DISCOURS furent les premières chansons," writes Jean-Jacques Rousseau in his "Essai Sur l'Origine des Langues.” For Rousseau (as for Wagner, a hundred years later) the original language was a song of immediacy, passion made voice just as need was made gesture. A hundred years after Wagner, we are still a hundred years after Wagner and still think of music as some unhindered discourse of the unconscious. It seems that two thousand years of craft have not been enough to expose the art as art. When it comes to music, both the Man in the Crowd and the man by the couch are alike, as alike are the women and Nomen of all chords, forever ready to reenact the soul to soul chanson.

“. . . kind of drunkenness (. . .) Thinking strictly prohibited," says Bloom to himself as he thinks of Father Cowley's piano playing and of music enthusiasts in general. But music as a drug, music as Tristan's truth potion, is a modern idea, no more than two centuries old. By the time Rousseau was writing his Essay, the sound of music was not the one we know. For the "kapellmeister," steeped in the doctrine of "affections," his art was one of representation rather than expression, an art of communal mimesis rather than individual confession. It is only during the early eighteenth century that originality and personal expenditure storm-and-stress into the game, as instrumental music gains prominence over vocal music and Carl Philipp, the son, Emanuel Bach, makes the shape of day with his own works and leaves behind the ghost of his dead father.

At this point, music once again becomes a form of speech, just as for Rousseau the first speech had been a form of music. "Il crut que la musique était une façon particulière de communiquer la pensée, et que les instruments, les vielles, les violons, les trompettes étaient entre nos mains d'autres organes de la parole," writes Diderot of the deafman. Immediacy 
becomes intimacy: the clavichord Fantasias are Carl Philipp's private phantasies made public, and the Fifth Symphony will be, for us, Beethoven. Whereas the composer as craftsman was the master of inventiveness and ease, proud to present his subtle art for everyone to hear, the genius as tone-poet conceals his craft to carve for us an image of selfhood. Immediacy now becomes a lover's knowledge of the other, and craft the ability to be at once invisible and present.

Between a ghostly music that conceals its art and a ghostly art that bears no seal of subject, the art of music weaves its craft of secrecy and illusion. It thematizes time, yet it is removed from time. Beyond the lure of a truly continuous present, music lives as architecture, since form, time past, is always present here, in time present, music's only speaking tense. Immediacy is craft - ebbing and flowing to the laws of tidal ears. A double bind, bound airs are bound so that they too be binding. Against such powers, no escape but other forms of binding.

Against the Sirens' song, against the song of the Binders, Odysseus has no weapon but a rope, with which he has himself bound to the mast. To hold him still, Perimedes and Eurylokhos, cunning and ambush in their very names, will pass more line around him, as he begs to be untied. The threat of song is the threat of forgetfulness: the closer one may get to this green mirror, the deeper one escapes from oneself into oneself. The Neapolitan Sirensong will make no time of time, will blend sense and desire, will blur the line between craft and content. The moment of thrust is the moment of delusion-not vision, not satori, but rather, alienation.

The brief encounter of song will repeat, in measured time, the brief encounter of sailor and bird-women. The silence in which songs dwell is the silence of mid-morning, brief love spent. Songs and Sirens love but for a few moments. Reconciled with nature, reconciled with each other, lover singers and lover listeners soar "in the effulgence symbolistic," intoxicated by sentiment, "high, of the etherial bosom," high, icharian flights, icharian fugues, "throb, a throb, a pulsing proud erect," infinite while it lasts, "all soaring all around about the all," wagnerian master singers of the "endlessnessnessness ...."And Joyce's sentences mime the affected mannerism of a sincere song-like Joe Hynes' ode to Parnell (in "Ivy Day in the 
Committee Room"), or John F. Taylor's impromptu, as remembered by J. J. O'Molloy in the office of the Evening Telegraph - pastiche here becomes at once exposure and achievement, style both cessation and the only possibility for speech.

There is a sense in which every word here is pastiche. Every word, the narrators' no less than their characters', is marked by some practice of writing or of speech. Each word, each song, each gesture, is allusion; each character, a charakter, an engraving. Rather than the book as world, it is the world as book that's in the making, "signatures of all things I am here to read." Each word, each song, each sign of life becomes, for us, the epiphany of style - the epiphany of an institutional performance.

Style makes man, speechcraft the author. Style holds the pen before the artist, whose only counterword must be to set each language against every other, including his own. In this Gospel of Marks, then, each language will be made to account for its sins. The book becomes a collection of formal epiphanies, a workbook of Irish polyphony. The author as composer is the one who puts together all the voices, the master singer skillful on all manners of "affections," the contrapuntist playing diction against contradiction, the craftsman who presents his art for everyone to see.

Trope and pun are perhaps the most conspicuous features of this art, and both combine to help jam the literary engine. The trope will give the lie to the naturalness of language, and make of every speaker an orator, a rhetor, a cultured man who learns to scatter words. The pun, in its turn, shortcircuits thought as it makes one think not of this or that meaning, but rather of both and none at once. To these we may add irony, which turns everything said into its opposite; and what might be called the narrative ataxy, the constant shift of narrative voice and rhythm. The multiplicity of narrative points of view will be forever cancelling the voice of reconciliation, the voice of the wisdom dispenser, as successive changes of strategy will make belief improbable, unlikely, even impossible. No sooner is fable started than the clerk of works lays bare the machinery of the bookwork. Nothing taken for granted, nothing given; every figure is made, every meaning is produced. Faced with so much that is artificial, we have no choice but to begin to read. 
We begin at the beginning, with an overture. Retrospective writing made of this a prospective arrangement; retrospective reading wakes synoptic writing here. The world in a word is still at bay, but already we are stunned at the sight of its Environs. Like the operatic medleys which it emulates, this opening is all cymbals and fireworks on a first hearing. Subsequent readings hear an hour in every minute, hear in this two-page ideogram all the chatter and the silences of thirteen hundred lines. As Almidano Artifoni moves across the page to take his place in front of the Ormond Orchestra, the royal cavalcade fades out of view and brings to a stop the Wandering Rocks. The overture that is a prelude puns across the arts to mirror the preceding epilogue, albeit on a different tone and key. The prelude that is an overture clipclaps full tups like opera: all cymbals and fireworks it leads one to expect anything but Water Music.

A few measures into this opening, we have begun to lose our faith in grammar. By the time it's done, eppripfftaph pfrwritt, we may be sure that no further closures will be allowed to go unscathed, unread. Up to this point, the question, "Who is speaking?" was occasionally difficult to answer. In the overture, however, it becomes not difficult to answer, but impossible to ask. Once the narrative is punctured, the narrators cannot sustain their breath. From now on, a writerly writer will stage-manage the show, like a Deus in machina. That he too will become readerly fiction almost goes without saying. The overture of the opera is the opening of the works.

That this should be happening in a chapter which is ostensibly concerned with music cannot be mere coincidence, in a book where coincidence is law. ("It is. Again. Third time. Coincidence," thinks Bloom as he eyes the gay hat riding on a jaunting car on Essex sexbridge - the bridge that draws apart.) For what is in question is a posited neutrality of representation, and that is the age-long lie of music, "magic lyer," a lie that is still with us. Ask a musician "Who is speaking?" and you're sure to get a horn blow in reply. That this should be happening in a chapter which is no less ostensibly about sighs and lips and smiles cannot be mere coincidence, in a book where coincidence is law. ("The number three, which rounds things," writes Borges. "Two is a mere coincidence, three is a confirmation"-a signature.) From the Sirens to the songs to the scriptures, immediacy is a 
question of belief, of trust and thrust. The throstle crafts its tone, Miss Douce rings bells: "Sonnez! Sonnez la cloche!" Sonnez les machines! Smack, ding, done.

The fugue that follows, if it is a fugue, must be so more for its names and for the history of its form than for an unlikely but much-believed but never shown parallelism. From a strictly musical point of view, the chapter makes more sense as an operatic act, complete with introduction, duets, a tenor aria, a trio, a quintet, a baritone solo, and several comings and goings, than as a fugue, which would not have allowed for such variety. And as for the overture, it makes no sense at all to speak of it as a prelude, unless it be an operatic prelude. But the fugue provides what writing needs and cannot find in opera: a lexicon, a source of tropes and emblems of its art. Here too the universe seems to have been arranged for Joyce's convenience. Suffice it to list a few technical words to show what chance had come up with in the way of necessity: "subject," "countersubject," "episode," "dux" (a guide), "comes" (the one that goes, and in this particular case the one that comes), "fuga" (flight or chase), "augmentation," "diminution," "stretto" (tight or bound), "lydian," "mirror form," "invertible canon," "retrograde imitation." And as if this were not enough, the first recorded reference of the word "fugue" appears in Jacques de Liège's fourteenth-century work, Speculum Musicae, music's mirror.

The fugue as emblem stands as virtual heading for the chapter. An academic test piece for composers, the fugue is the most fully developed form of polyphonic writing. That one might actually write music while still abiding to so many hard and fast conventions must be something of a minor mystery to those who think of music as the last and only form of unmediated art. That one might write truly great music while still abiding by such slow conventions remains a major mystery for those who know it is not. What polyphony seems to be telling us is that culture at its highest may breed nature at its most intense, and that, indeed, perhaps there is no other way for us to go so low.

Miss Douce and the seashell against a gildedlettered mirror: an emblem cast as image for a chapterhead. A miss a sweet against a mirrored letter of outcry. Miss Mina Douce is Siren and is Mina-bird, a bird that is often 
tamed and taught to speak. She learns a false high language and a lip wish show of solitude. What the "cloche" smack seems to tell us is that nature at its highest may breed culture at its most intense, and that, indeed, there is perhaps no other way for us to go so low.

Nature speaking culture and culture speaking nature find their ready-made emblem on the seashell. "Listen! she bade him," and George Lidwell, solicitor, heard wonderful sea waves on calcium coil. Then pale gold in contrast glides to hear. But Bloom, from the dining lounge, hears better, "more faintly that that they had heard, each for herself alone, then each for other, hearing the plash of waves, a silent roar." What the shell seems to be telling us is that nature and culture share one space, and that, indeed, there is no other way for us to go.

A straight line and a shell is how Brancusi painted Joyce. Both are labyrinths, infinite labyrinths in opposite directions. Both straight and coiled line are marks of time, abstracted from time by the geometer, who knows that that same line and that same spiral have run and coiled through the lives of all geometers, as they will coil and run through his own too. The movement of music is the music of line and of sea spiral, and both at once: always a present tense that is fading, and always ourselves who are fading in. The medieval "musica poetica," music as composition, is the secret consolation of the medieval "musica pratica," music as music-making, music as "meditatio mortis." Time signatures will countersign that time which is their substance; each moment fixed in its own contradiction, composed to be eternally repeated. The Sirensong will blend sense and desire, will blur the line between craft and content, will make no time when time, forgotten, is at its most intense.

"Of course the unskilled singer continues to pervert our wiser ears by subordinating the space-element, that is to sing, the aria, to the time-factor, which ought to be killed, ill tempor" (FW 164). And just like the shell reverses the infinite of line by folding line upon itself, so Joyce's music lines will send the letter back to sender, will bend the grammar against its own grain. Permutation and echo will do the trick: "Miss Kennedy sauntered sadly from bright light, twining a loose hair behind an ear. Sauntering sadly, gold no more, she twisted twined a hair. Sadly she 
twined in sauntering gold hair behind a curving ear." A curving ear: "Her ear too is a shell," thinks Bloom of weary gold by bronze. A bass clef, a seashell, a curving ear; a bar, a bed and board of keys to play one selfsame tune.

Joyce the composer had the ear of a foreigner, fascinated by the uncommon sound of common tongues. His playful paper music is a virtuoso exercise in an individual style of cross-art punning, what we might call a style of "synegraphy," in one and only one sense of the word. There is no doubt that the vocabulary of classical rhetoric can well describe most, if not all, of such synegraphic puns. With time and care and glossaries we might be able to print an extensive list of illnesses to be found in this chapter, including apheresis, apocope, anadiplosis, prosthesis, epenthesis, gemination, tmesis, coluthon, ellipsis, and contamination, among others. But such a diagnosis, while hitting signs, would be missing symptoms. The chapter's surface charm is charming from the spell to the incantation, from the enchantment to the chant. The appogiatura "Luring. Ah, alluring," the portamento "Diddle, iddle, addle, ooddle, ooddle," the hollow fifths "Why did she me?" or "Blmstup," and the long fermata on "endlessnessnessness ..." make choice of chance and chime: "endnessnessessity!" (FW 613). And then there is that large collection of what can only be described as some literal form of word painting, not in the sense of Renaissance and Baroque melodic mimicry, but rather as a sight of sense on page. "wavyavyeavyheavyeavyevyevyhair un com:'d" combines image and synegraphic trill at end of cadence. Both "endlessnessnessness ..." and "imperthnthn thnthnthn" are examples of onomatopoeic design, that same typographic art which would allow for "Pprrpffrrppffff." In this context, even "bootssnout" and "footstool" begin to look like ideograms; in this context, even "Sleep!" or "bob" or ":" make reading visual. Later on, in nighttown, The Bells will clatter "Haltyaltyaltyall," and be answered by The Gong's "Bang Bang Bla Bak Blud Bugg Bloo." All this is strange mute music, to be played painted on the printer's galley. Song chapter, as speech wind chapter, will make, have made, us, look, at, words, for all they're worth.

Joyce the foreigner is incessantly composing sign for song, incessantly translating culture's cult to expose the singing. The Old Serpent will coil 
to bite his tale, but the Old Teaser, not a foreigner, but an exile, is here to accuse, slander, traduce, like a Greek "diabollos," the one that throws across, that makes language of tongue, uncommon babble. Emblems cast, the devil of the village, like a Diabolus ex machine, will come through unlikely souls to draw his moral.

- The tuner was in today, miss Douce replied, tuning it for the smoking concert and I never heard such an exquisite player.

-Is that a fact?

- Didn't he, miss Kennedy? The real classical, you know. And blind too, poor fellow. Not twenty I'm sure he was.

-Is that a fact? Mr. Dedalus said.

He drank and strayed away.

- So sad to look at his face, miss Douce condoled.

God's curse on bitch's bastard.

Tink to her pity cried a diner's bell. To the door of the bar and diningroom came bald Pat, came bothered Pat, came Pat, waiter of Ormond. Lager for diner. Lager without alacrity she served.

So they come together, the palindromes Pat and Tap, the stripling and the bothered, immune to the charms of "Wine, Women and Waterclocks," the eyeless and the hard of hearing, steering clear of Sirens' rocks and roll. Inversion here seems to be subversion, turning, trope: when Joyce is fixed on common words, we'd better join the poet to his underword. "Bothered Pat, the waiter," who, bothered, waits while you wait, whose family waits for him, who waits while you wait. "How will you pun?" Why bother? Because old Irish "bodar" is akin to Welsh "byddar," both meaning deaf. While wait? Because the wait is to the watchman as the waiter is to the counterman, a man who stands by the place of accounts, a man of thought. Bothered Pat the waiter is none other than deaf Pat, the watcher counterman. And as for the blind tuner, the stripling, Mr. Penrose, he'll tune not only piano keys but clefs of rhetoric too. For a tone is "the element in discourse that expresses the speaker's sentiment and reveals his character," according to the Funk \& Wagnalls Standard Dictionary of the English Language. And a stripling, a mere youth, is also one who strips, uncovers, plunders. But "my herrings! The surdity of it!" - "the last word in stolentelling." What can we make of deaf watcher and blind word stripper, back to back as one? 
"Putting truth and untruth together a shot may be made at what this hybrid was actually like to look at" (FW 169). ". . . all ears, an artificial tongue with a natural curl ..." Shame's choice made necessity of chance, and exile taught him to play blind and see. At once home and abroad, uncommon common seen will strip blind craft of all immediacy. With magic cane, the stripling taps his way to the Ormond Bar, Allemonde in Dublin. His tapping beats the beating of old men and maidens playing with themselves, and it beats the curse of God on all bitch's bastards. This tuner's wand is Protean Stephen's ashplant, as he walks blind along Sandymount Strand; it's Bloom's baton, a rolled copy of the Freeman; it is the stick of genius for the greatest blind, Tiresias, Homer, Milton, Prescott, Bach; it's the rod of reading blindness for the sighted, Aaron the priest, and Hermes messenger, Dionysus, Christ as shepherd, Blake's Los, Handel, Thoth, and-last but not least-Maistre Sheames de la Plume, sham and low sham, joky for Jacob, progenitor of the Israelites.

Against the Zurich stream, stands Aloysius, cane on hand. At his son's home in Paris, his grandson handles his grandfather's rod. Brancusi paints him seashell by a stick. This old white-bearded Sathan, villainous, abominable, and mis-leader of Youth, points with false staff to stave and undersong. Deafness, blindness, silence, make the cunning of the exile, who will not see what's seen, nor hear what's heard. From the heart of the hibernian metropolis, from a piano bar in the afternoon of cuckoldry, the blind master intones his psalm, in modus peregrinus: “'Tis Optophone Which Ontophanes": a letter on the blind, for the benefit of those who see, a letter on the deaf and dumb, for all of us who cannot hear or speak. 